\title{
EFEKTIVITAS PENGGUNAAN MEDIA POWERPOINT DALAM MENINGKATKAN HASIL BELAJAR SISWA PADA MATA PELAJARAN PENERAPAN KONSEP MUTU HASIL PERTANIAN
}

\section{The Efektiveness of the Using Powerpoint Media to Increase Student's Learning Achievement In The Application Concept Quality of Agricultural Subject}

\author{
Oleh: \\ 1Salmiah, ${ }^{2}$ Anwar Fatah, ${ }^{3}$ Purnamawati \\ 1)Mahasiswa Program Studi Pendidikan Teknologi Pertanian FT UNM, \\ 2) dan 3)Dosen FT UNM
}

\begin{abstract}
ABSTRAK
Penelitian ini merupakan penelitian tindakan kelas yang bertujuan untuk meningkatkan hasil belajar siswa dalam pembelajaran penerapan konsep mutu hasil pertanian siswa kelas X TPHP SMK Negeri 3 Takalar. Subjek dalam penelitian ini adalah 21 siswa. Prosedur penelitian meliputi tahap perencanaan, pelaksanaan, observasi dan refleksi. Data yang terkumpul dianalisis dengan menggunakan data kualitatif dan kuantitaif. Berdasarkan hasil penelitian, dapat disimpulkan bahwa penggunaan media pembelajaran powerpoint dapat meningkatkan hasil belajar siswa. Hal ini terbukti pada pra siklus, siklus I dan siklus II hasil belajar siswa terus meningkat.

Kata Kunci: Efektivitas, PowerPoint, Peningkatan Hasil Belajar

\section{ABSTRACT}

This is class action research which aimed to improve the student's achievement in plant aplication concept quality of agricultural at the $X$ class in SMK Negeri 3 TPHP Takalar. The subjects of this research consisted of 21 student's. Recearch procedure includes planning implementation, observations and reflection. The data that has been collected; is analyzed using quantitative and qualitative data. Based on the result of the research, it can be concluded that the aplication of Powerpoint media can improve the student's achievement. The result of the pre-cycle, cycle I and cycle II that has a significant improvement.
\end{abstract}

Keyword: effectiveness, Powerpoint, Student's achievement

\section{PENDAHULUAN}

Pendidikan

merupakan

kebutuhan manusia selama hidup, tanpa adanya pendidikan maka dalam menjalani hidup ini manusia tidak akan berkembangbahkan akan terbelakang dalam mencapai suatu tujuan pendidikan. Dengan demikian pendidikan itu harus betul-betul diarahkan untuk menghasilkan manusia yang berkualitas yang mampu bersaing, memiliki budi pekerti yang luhur dan moral yang baik.
Kemajuan ilmu pengetahuan dan teknologi memiliki pengaruh yang sangat besar dalam berbagai bidang kehidupan manusia. Pendidikan sebagai salah satu bagian yang tidak terpisahkan dari proses pendewasaan manusia tentu di satu sisi memiliki andil yang besar bagi pengembangan ilmu pengetahuan dan teknologi tersebut, namun di sisi lain pendidikan juga perlu memanfaatkan kemajuan ilmu pengetahuan dan teknologi agar mampu mencapai tujuannya secara efektif dan efisien (Ali 
Muhson, 2010). Guna meningkatkan efektivitas dan efisiensi pembelajaran, perlu dikembangkan berbagai model pembelajaran yang kreatif dan inovatif. Hal ini perlu dilakukan agar proses pembelajaran tidak terkesan kurang menarik, monoton dan membosankan sehingga akan menghambat terjadinya transfer of knowledge. Oleh karena itu peran media dalam proses pembelajaran menjadi penting karena akan menjadikan proses pembelajaran tersebut menjadi lebih bervariasi dan tidak membosankan (Ali Muhson, 2010).

Bahan pengajaran yang dimanipulasikan dalam bentuk media pengajaran dapat menjadikan peserta didik belajar sambil bermain dan bekerja. Dengan menggunakan media pembelajaranakan lebih menyenangkan siswa. Oleh karena itu seorang guru atau pendidik harus mampu memanfaatkan media pembelajaran.

Berbagai faktor yang menjadi penghambat proses pembelajaran, dan motivasi belajar siswa merupakan salah satu faktor yang menyebabkan rendahnya hasil belajar siswa. Adanya anggapan dari seorang siswa dan guru bahwa mata pelajaran menerapkan konsep mutu hasil pertanian dan pengendalian mutu hasil pertanian dalam pengolahan hasil pertanian cenderung membosankan karena penggunaan media dan metode yang kurang bervariasi (monoton) sehingga siswa kurang Untuk mengatasi masalahmasalah tersebut, salah satu penyelesaian untuk meningkatkan hasil belajar siswa adalah dengan mengunakan media powerpoint dalam proses kegiatan belajar mengajar.

\section{TUJUAN PENELITIAN}

Tujuan penelitian ini adalah untuk mengetahui hasil belajar siswa kelas X.2 TPHP SMK Negeri 3 Takalar dengan media powerpoint pada mata pelajaran menerapkan konsep mutu hasil pertanian dan pengendalian mutu hasil pertanian, serta untuk mengetahui efektivitas pengunaan media powerpoint terhadap pembelajaran pada mata pelajaran menerapkan konsep mutu hasil pertanian dan pengendalian mutu hasil pertanian

\section{METODE PENELITIAN}

Jenis Penelitian

Penelitian ini merupakan Penelitian Tindakan Kelas (Classroom Action Research). Suharsimi Arikunto (2010) penelitian tindakan kelas (PTK) adalah penelitian tindakan yang dilakukan oleh guru, bekerjasama dengan peneliti dengan tujuan memperbaiki mutu praktik pembelajaran di kelasnya.

\section{Desain Penelitian}

Secara garis besar, terdapat empat langkah dalam melaksanakan penelitian tindakan kelas ini (Mulyasa, 2013), yaitu perencanaan (Planning), pelaksanaan (Acting), pengamatan (Observing), dan refleksi (Reflecting).

\section{Lokasi dan Waktu Penelitian}

Lokasi penelitian ini dilaksanakan di SMK Negeri 3 Takalar, Desa Kunjung, Kecamatan Sanrobone, Kabupaten Takalar. Waktu penelitiannya pada semester genap tahun ajaran 2014 / 2015

\section{Subjek Penelitian}

Subjek yang dijadikan pada penelitian ini adalah siswa X.2 TPHP di SMK Negeri 3 Takalar. Jumlah siswa dikelas ini sebanyak 26 orang yang terdiri dari 10 orang laki-laki dan 16 siswa perempuan, namun yang menjadi sampel dalam penelitian ini adalah 21 
orang siswa yang terdiri dari 7 siswa lakilaki dan 14 siswa perempuan.

\section{Teknik dan Instrumen Pengumpulan Data}

Teknik dan instrumen pengumpulan data yang digunakan dalam penelitian ini adalah wawancara, tes, lembar observasi dan Kuesioner.

\section{HASIL PENELITIAN}

\section{Hasil tes awal (Pre - Test)}

Sebelum peneliti menerapkan tindakan yang direncanakan yaitu penggunaan media powerpoint, terlebih dahulu mengadakan tes awal (Pre-Test) untuk mengukur sejauh mana pemahaman siswa tentang materi yang diberikan, tes awal juga bertujuan sebagai pembanding hasil penggunaan media powerpoint.

Nilai atau skor rata-rata yang diperoleh siswa pada mata pelajaran penerapan konsep mutu hasil pertanian dan pengendalian mutu hasil pertanian setelah dilakukan tes awal (Pre-tes) adalah 41,11 dari nilai ideal yaitu 100 dari tiga puluh soal pilihan ganda, diaman nilai tertinggi yang diperoleh adalah 51, nilai terendah adalah 28 , kemudian rentang skor adalah 23. Berdasarkan data tersebut dapat disimpulkan bahwa tes hasil belajar peserta didik pada awal tes (Pre-tes) belum tuntas atau belum memenuhi kriteria yang telah ditetapkan yaitu KKM (70). Dari 21 siswa yang dijadikan subjek dalam penelitian, ternyata 18 siswa dengan persentase $85, \quad 71 \%$ dikategorikan dengan tingkat penguasaan yang sangat rendah, 3 siswa dengan persentase $14,28 \%$ dikategorikan dalam tingkat penguasaan rendah.

$\begin{array}{cr}\text { Rendahnya } & \text { persentase } \\ \text { ketuntasan belajar } & \text { siswa, dimana }\end{array}$ ketuntasan belajar $0 \%$ atau 21 siswa dari 21 siswa belum tuntas belajar. Hasil tersebut menunjukkan bahwa pada tes awalsecara klasikal belum tuntas belajar, karena siswa yang memperoleh nilai $\geq$ 70 sebesar $0 \%$ atau dinyatakan tidak ada yang tuntas belajar. Dari hasil tes awal ini dapat dilihat bahwa banyaknya siswa yang tidak mencapai satndar KKM (70) pada mata pelajaran penerapan konsep mutu hasil pertanian.

\section{Hasil penelitian siklus I}

Hasil kajian dari 21 orang siswa sebagai sampel dalam penelitian, ternyata 2 orang dikategorikan dengan tingkat penguasaan rendah dengan persentase $9,52 \%, \quad 5$ orang dikategorikan dalam tingkat penguasaan yang sedang dengan persentase 23,81 $\%, 10$ orang dikategorikan dalam tingkat penguasaan tinggi dengan persentase $47,61 \%$, dan sebanyak 4 orang dikategorikan dalam tingkat penguasaan yang sangat tinggi dengan persentase $19,04 \%$.

Persentase ketuntasan belajar siswa adalah $66,65 \%$ atau ada 14 siswa dari 21 siswa sudah tuntas belajar, sedangkan $33,33 \%$ atau 7 siswa dari 21 siswa tidak tuntas belajar. Hal ini berarti bahwa terdapat 7 siswa yang perlu perbaikan karena belum mencapai kriteria ketuntasan belajar. Hasil tersebut menunjukkan bahwa pada siklus I secara klasikal belum tuntas belajar, karena siswa yang memperoleh nilai $\geq 70$ hanya sebesar $66,65 \%$ lebih kecil dari persentase ketuntasan yang dikehendaki yaitu sebesar $80 \%$. Hal ini disebabkan karena masih banyak aktivitas siswa yang rendah, sehingga kurangnya pemahaman yang siswa dapatkan selama pembelajaran. Kemudia salah satu faktor penyebab rendahnya hasil belajar pada mata pelajaran penerapan konsep mutu hasil pertanian dan 
pengendalian mutu hasil pertanian adalah media powerpoint yang masih membutuhkan sesuatu yang menarik agar dapat menumbuhkan rasa semangat siswa untuk belajar. Penelitian ini perlu dilanjutkan pada siklus berikutnya karena berdasarkan tujuan yang ingin dicapai peningkatan hasil belajar belum tuntas.

\section{Hasil Penelitian Siklus II}

Untuk mengatasi kekurangankekurangan yang terdapat pada pelaksanaan siklus I yang telah dilakukan, maka tindakan siklus II dilakukan dan dimaksudkan untuk memperbaiki kekurangan-kekurangan sebagaimana terurai dalam refleksi siklus I. Dalam pelaksanaan tindakan siklus II ini tidak ada yang berbeda pada siklus sebelumnya yaitu dengan mengacu pada langkah perencanaan (planning), pelaksanaan (action), pengamatan (observe), dan refleksi (reflect).

Skor rata-rata belajar siswa pada mata pelajaran penerapan konsep mutu hasil pertanian dan pengendalian mutu hasil pertanian setelah dilakukan tes akhir siklus II adalah $84,21 \%$ dari nilai ideal yaitu 100 , nilai tertinggi yang diperoleh adalah 98, nilai terendah 64 dan rentang skor adalah 31. Berdasarkan data tersebut dapat disimpulkan bahwa tes hasil belajar peserta didik pada siklus II mengalami peningkatan lebih baik dari siklus I dan sudah memenuhi nilai kriteria yang telah ditetapkan yaitu KKM (70).

Hasil kajian dari 21 siswa yang dijadikan subjek dalam penelitian, ternyata 0 siswa dengan persentase $0 \%$ dikategorikan dengan tingkat penguasaan yang sangat rendah, 0 siswa dengan persentase $0 \%$ dikategorikan dalam tingkat penguasaan yang rendah, 3 siswa dengan persentase $14,28 \%$ dikategorikan dalam tingkat penguasaan sedang, 3 siswa dengan persentase $14,28 \%$ dikategorikan dalam tingkat penguasaan tinggi dan 15 siswa dengan persentase $71,42 \%$ dikategorikan dalam tingkat penguasaan sangat tinggi.

Diperoleh persentase ketuntasan belajar siswa adalah $85,71 \%$ atau ada 18 siswa dari 21 siswa sudah tuntas belajar, sedangkan $14,28 \%$ atau 3 siswa dari 21 siswa tidak tuntas belajar. Hasil tersebut menunjukkan bahwa pada tes akhir siklus II (Post-Test) secara klasikal sudah tuntas belajar, karena persentase siswa yang diperoleh yaitu $85,71 \%$ sesuai atau sudah memenuhi persentase ketuntasan yang dikehendaki yaitu $80 \%$. Hasil pada siklus I lebih baik dari siklus II. Adanya peningkatan hasil belajar pada siklus II ini dipengaruhi odeh adanya peningkatan kemampuan aktivitas guru dan aktivitas siswa dalam proses pembelajaran dengan menggunakan media powerpoint sehingga siswa dapat menambah pengetahuan tentang materi yang telah diberikan dan adanya gambar-gambar yang ditampilkan dalam slide microsoft powerpoin pada materi penerapan konsep mutu hasil pertanian dan pengendalian mutu hasil pertanian sehingga membuat pembelajaran menjadi lebih menarik.

Hal ini berarti bahwa penelitian ini tidak perlu dilanjutkan pada siklus berikutnya karena berdasarkan tujuan yang ingin dicapai, yaitu terjadi peningkatan hasil belajar yang dinyatakan berdasarkan kriteria hasil belajar mengenai ketuntasan kelas secara klasikal, yaitu $80 \%$ dari jumlah siswa yang tuntas, data hasil penelitian pada siklus II di atas dianggap tuntas dikarenakan siswa yang sudah tuntas telah mencapai $85,71 \%$.

Hasil penelitian yang telah dilakukan dengan penggunaan media 
powerpoint dalam pembelajaran pada mata pelajaran penerapan konsep mutu hasil pertanian dan pengendalian mutu hasil pertanian diperoleh adanya peningkatan hasil belajar pada siswa kelas X.2 Teknologi Pengolahan Hasil Pertanian (TPHP) SMK Negeri 3 Takalar.

Penggunaan media powerpoint dalam pembelajaran yang diterapkan seorang guru merupakan salah satu faktor yang menentukan ketercapaian hasil belajar peserta didik, karena penggunaan media yang sesuai dengan materi yang disajikan akan mempengaruhi minat dan aktivitas peserta didik dalam mengikuti pelajaran yang pada akhirnya akan berpengaruh terhadap hasil belajar. Media powerpoint sangat mendukung hasil penelitian yang telah diperoleh.

Peningkatan hasil belajar peserta didik telah mencapai standar KKM untuk mata pelajaran penerapan konsep mutu hasil pertanian yaitu 70,00 serta mencapai ketuntasan klasikal yaitu $80 \%$ dari jumlah peserta didik yang ada. Hal ini dapat dilihat dari hasil belajar peserta didik kelas X.2 TPHP yang menunjukka nilai ketuntasan yang diperoleh dari hasil tes awal yaitu jumlah peserta didik yang tidak tuntas 21 siswa atau $100 \%$ dan jumlah yang tuntas sebanyak 0 siswa atau $0 \%$, kemudian pada hasil belajar siklus I dengan jumlah peserta didik yang tidak tuntas sebanyak 7 siswa atau $33,33 \%$ dan jumlah peserta didik yang tuntas sebanyak 14 siswa atau $66,65 \%$. Kemudian, pada hasil belajar siklus II (pos-test) dengan jumlah peserta yang tidak tuntas sebanyak 3 siswa atau $14,28 \%$ dan jumlah peserta didik yang tuntas sebanyak 17 siswa atau $85,71 \%$.

Hasil penelitian di atas, media powerpoint dalam proses pembelajaran mampu meningkatkan hasil belajar peserta didik. Penggunaan media powerpoint dalam proses pembelajaran memberikan kesempatan kepada peserta didik untuk aktif dalam proses pembelajaran dimana dalam pembelajaran, aktivitas siswa sering terjadi tanya jawab sehingga dapat meningkatkan daya ingat mereka tentang materi yang diberikan, kemudia dalam presentase dengan menggunakan media powerpoint yang mampu menyajikan teks, gambar, animasi,lagu dan lain-lain sehingga menimbulkan pengertian dan ingatan yang kuat. Hal inilah yang dapat mengakibatkan hasil belajar siswa meningkat.

\section{KESIMPULAN}

Dalam proses pembelajaran pada mata pelajaran penerapan konsep mutu hasil pertanian dan pengendalian mutu, dapat meningkatkan hasil belajar siswa kelas X.2 TPHP SMK Negeri 3 Takalar. Dimana pada tes awal siklus I (pre-test) nilai ketuntasan belajar siswa $0 \%$ dan pada tes akhir siklus I (pos-test), ketuntasan belajar siswa meningkat sebesar 14 siswa atau 66,65\%, kemudian terjadi peningkatan pada tes akhir siklus II (pos-test) dengan nilai ketuntasan belajar siswa sebesar 17 siswa atau $85,71 \%$.

Penggunaan media powerpoint dalam pembelajaran tersebut mempunyai efektivitas yang tinggi dimana terlaksananya semua tugas pokok atau tercapainya tujuan dan adanya pasrtisipasi aktif antara guru dan siswa. Kemudian terjadinya penigkatan rata-rata aktivitas siswa dari setiap siklus, yaitu pada siklus I dengan pesentase $47,88 \%$ dan pada siklus II dengan persentase $54,76 \%$. Selain itu,peningkatan ketuntasan hasil belajar siswa dalam setiap siklus, yaitu sehingga dengan demikian dapat simpulkan 
bahwa ketuntasan yang diperoleh yaitu $85,71 \%$ dengan kategori sangat efektif.

\section{DAFTAR PUSTAKA}

Ali, Muhson. 2010. Pengembangan Media Pembelajaran Berbasis Teknologi Informasi. Jurnal Pendidikan Akuntansi Indonesia, (on line), vol. VIII. no. 2,HIm110,(http://download.portal garuda.org/article. php?article $=52$ $483 \&$ val $=480$, diakses tanggal 13 januari 2015).

Mulyasa. 2006. Manajemen Berbasis Sekolah; Konsep, Strategi dan Implementasi. Bandung: Remaja Rosdakarya 